\title{
Length-weight relationship, body condition, and fishing gear selectivity of shortfin scad (Decapterus macrosoma) landed in Banjarmasin fishing port, Indonesia
}

\begin{abstract}
Ahmadi
Received - 06 February 2020/Accepted - 20 April 2020. Published online: 30 June 2020; Inland Fisheries Institute in Olsztyn, Poland Citation: Ahmadi 2020 - Length-weight relationship, body condition, and fishing gear selectivity of shortfin scad (Decapterus macrosoma) landed in Banjarmasin fishing port, Indonesia - Fish. Aquat. Life 27: 113-124
\end{abstract}

\begin{abstract}
The present study provides scientific information on the growth pattern and relative condition of shortfin scad, Decapterus macrosoma Bleeker landed in Banjarmasin fishing port, Indonesia. A total of 313 individual scad comprising 178 males and 135 females ranging from 152 to $225 \mathrm{~mm}$ total length and from 37 to $110 \mathrm{~g}$ weight were investigated. The body shape of both males and females showed isometric growth patterns indicating that all body dimensions grew at the same rate. The regression coefficient was significantly different between the sexes. The total length (TL), body weight (W), body depth (BD), W/TL, and BD/TL ratios and condition factors of the females were comparatively higher than those of males. The highest percentage of the catch was between 180 and $189 \mathrm{~mm}$ TL (32.59-40.45\%) and 50 and $59 \mathrm{~g} \mathrm{~W}$ (20.65-21.79\%). The relative condition factor values ranged from 0.799 to 1.433 , which reflected the good condition of the fish samples. The estimated length at first capture $\left(\mathrm{L}_{\mathrm{c} 50}\right)$ and selection factor values were $180 \mathrm{~mm}$ and 3.54 for males and $185 \mathrm{~mm}$ and 3.64 for females. In the present work, the purse seine was considered to be a male-biased gear, with a sex ratio of $1.3: 1$. The outcomes of this research could be useful for sustainable pelagic fisheries management and for developing precautionary measures to prevent the overexploitation of this species.
\end{abstract}

\footnotetext{
Ahmadi [ $\equiv]$

Faculty of Marine and Fisheries, Lambung Mangkurat University Banjarbaru 70714, South Kalimantan, Indonesia

e-mail: ahmadizarigani@gmail.com
}

Keywords: Decapterus macrosoma, Isometric, Masalima Sea, Banjarmasin fishing port

\section{Introduction}

The shortfin scad Decapterus macrosoma Bleeker is a commercially important pelagic fisheries resource that beneficially supports food supply and the fish processing industry, and it is also fish bait for the tuna longline fishing industry (Asni et al. 2019). It belongs to the family Carangidae, which is in high market demand locally as it is less expensive than other pelagic fishes. At least four species of scad mackerel inhabit Indonesian waters, i.e., Decapterus kurroides Bleeker, Decapterus macarellus (Cuvier), Decapterus russelli (Rüppell), and Decapterus macrosoma Bleeker (Atmaja and Sadhotomo 2005). These fishes are mostly caught with purse seines, gill nets, ring nets, mini-trawls, and rod and line fishing (Ohshimo et al. 2014, Narido et al. 2016). The scad fishery is very important in Indonesia, since it employs large numbers of fishers and takes a significant proportion of the total catch. However, high demand for these species has resulted in declining fish

(c) Copyright by Stanisław Sakowicz Inland Fisheries Institute in Olsztyn.

(c) 2020 Author(s). This is an open access article licensed under the Creative Commons Attribution-NonCommercial-NoDerivs License (http://creativecommons.org/licenses/by-nc-nd/3.0/). 
populations from overfishing or overexploitation (Kalhoro et al. 2017, Zamroni and Suwarso 2017).

Decapterus species are well-documented in several studies by researchers from Asian, European, and South Pacific countries that focus on growth and reproduction (Shiraishi et al. 2010, Ohshimo et al. 2014), growth and mortality (Mansor and Abdullah 1995), food and feeding habits (Jaiswar et al. 1993), feeding behavior (Ory et al. 2017), length-weight relationship and condition factor (Liestiana et al. 2015, Ashwini et al. 2016), population dynamics (Suwarni et al. 2015), optimization of enzymatic hydrolysis conditions (Rasli and Sarbon 2018), genetic diversity (Zamroni and Suwarso 2017), major allergen identification (Misnan et al. 2008), species description (Kimura et al. 2013), stock assessment (Kalhoro et al. 2017), factors affecting catches (Tsitsika and Maravelis 2006), bioeconomic analysis and resource management (Piliana et al. 2015), and market price analysis for this species (Nababan et al. 2014). Each species of the family Carangidae has own its characteristics, and they can exhibit different performance and behavior even in the same habitat (McBride et al. 2002, Ohshimo et al. 2006).

Managing the shortfin scad fishery resource rationally requires in-depth knowledge of its biology, feeding habits, and ecology (Narido et al. 2016, Asni et al. 2019). The length-weight relationship is the most common scientific approach used to analyze growth and morphometrics in individual fish species (Ongkers et al. 2016, Pattikawa et al. 2017) and also for understanding fish biomass and stock assessment (Kalhoro et al. 2017) of various species from different geographical regions. It is also useful for local and interregional morphological and life historical comparisons in species and populations (Sani et al. 2010, Shiraishi et al. 2010). Fish length is the best indicator of production efficiency (Ghorbani et al. 2012), while weight is considered to be a function of length (Weatherley and Gill 1987). According to Bagenal and Tesch (1978), heavier fish of a given length are in better condition. Fish condition is determined by the condition factor $(\mathrm{K})$, which is derived from the length-weight relationship. Information on the condition factor of scad is also required for determining gonad maturity and growth level (Shiraishi et al. 2010, Mehanna et al. 2015), as well as for monitoring stock assessments and fishery resource management (Piliana et al. 2015, Kalhoro et al. 2017).

It is acknowledged that changes in fish population structure in a certain area associated with fish life history (e.g., stock size and age structures) are greatly influenced by size-selective fishing gear (Jorgensen et al. 2009, Hsieh et al. 2010, Liang et al. 2014). Managing fishing practices without considering fish population stability directly and adversely affects not only ecosystem balance and biodiversity but also the socioeconomic impacts of the fisheries overall (Kigbu et al. 2014, Kalita et al. 2015, Hanif et al. 2019).

In South Kalimantan Province, the scad fishery contributes about $25 \%$ of the total catch landed. Based on daily reports issued by Banjarmasin fishing port authority, about 5-20 tons of scad are landed daily by one vessel, which is equal to $50-100$ tons landed by ten vessels (6-30 GT). A total of 1,808,700 $\mathrm{L} /$ year of the fuel quota is regularly provided by PT AKR Corporindo, Tbk, and it is distributed proportionally to each vessel group (Shafari et al. 2019). Banjarmasin fishing port has no fish auction center. All transactions of the marketing channels are organized by a fish distributor agent (Rahman et al. 2019). The wholesale and retail fish prices for fishers and consumers are IDR 12,000 and IDR 35,000, respectively. The fish price fluctuates seasonally depending on supply and demand. To draw a clear picture of scad fishery, we started investigating the length-weight relationship, body condition, and fishing gear selectivity of shortfin scad landed in Banjarmasin fishing port to provide some fundamental suggestions for better fisheries management.

\section{Materials and Methods}

The shortfin scad were caught with purse seines from the Masalima Sea around Makassar Strait, which was part of Fisheries Management Area 713 


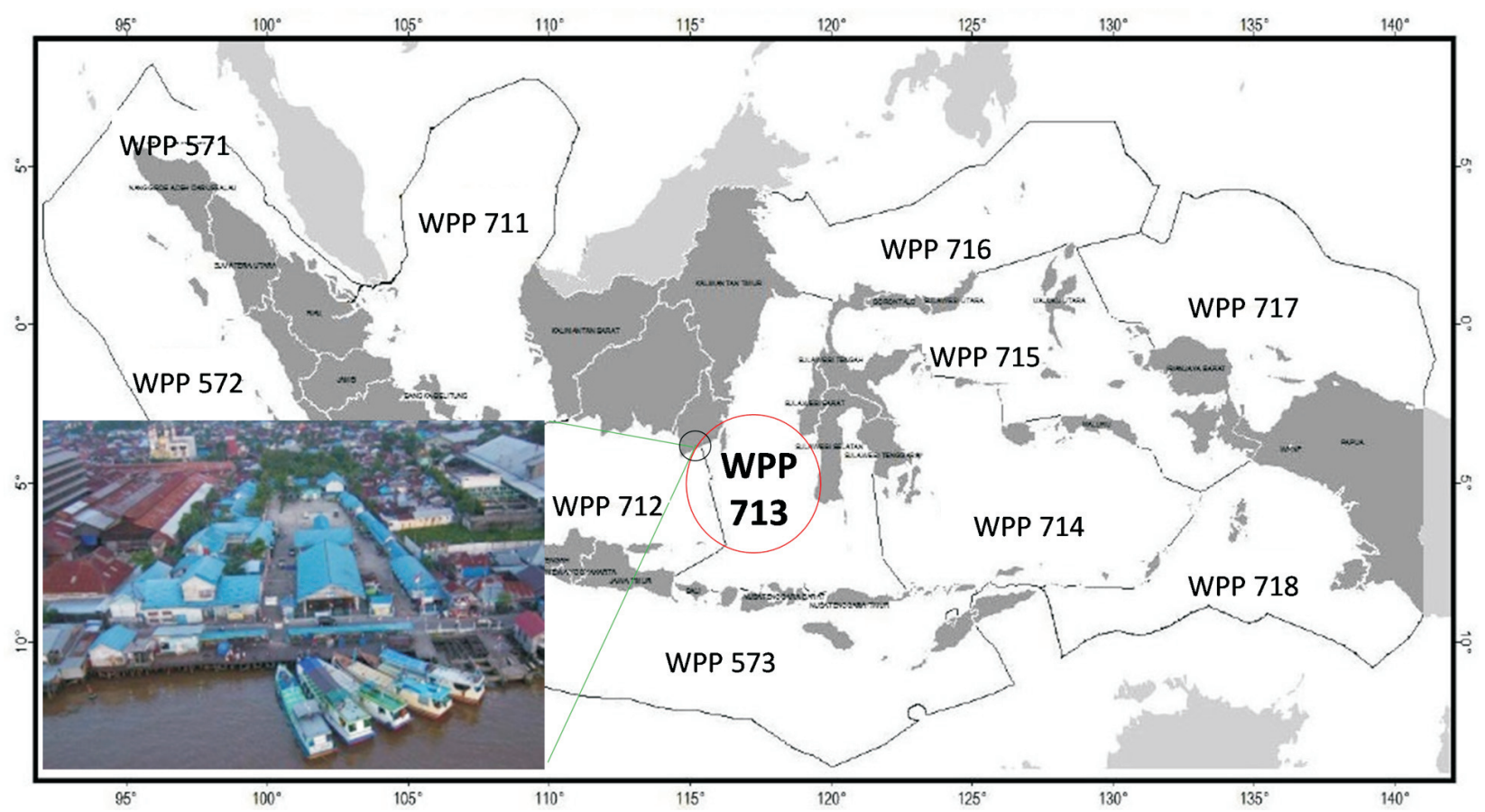

Figure 1. Location of Masalima Sea in Fisheries Management Area/WPP 713 (red circle) and Banjarmasin fishing port (black circle link with a photograph)

(WPP-713), Indonesia. The catch was transshipped from purse seiners (100-175 GT) to fish carrier vessels (25-30 GT) for landing in Banjarmasin fishing port in South Kalimantan Province (Fig. 1), located at $03^{\circ} 18^{\prime} 03^{\prime \prime} \mathrm{S}$ and $114^{\circ} 33^{\prime} 02^{\prime \prime} \mathrm{E}$. This fishing port is one of the regional technical implementing units (UPTD) under the Marine and Fisheries Service of South Kalimantan Province. The fishing port was built in 1975, and it is the oldest fishing port on Kalimantan Island. It is very strategic area because it is accessible by fish carrier vessels from both Java and Sulawesi.

A total of 313 individuals of shortfin scad comprising 178 males and 135 females were purchased directly from Banjarmasin fishing port. The fish were measured for total length (TL), body depth (BD), and weight $(\mathrm{W})$. Total length was taken from the tip of the snout to the extended tip of the caudal fin. Body depth was measured from the dorsal fin origin vertically to the ventral midline of the body. The total length and body depth of each individual were measured with a ruler to the nearest $1 \mathrm{~mm}$, while whole body weight was determined on a digital scale to the nearest $0.01 \mathrm{~g}$ (CE, SF-400, China). The size distribution of the fish sampled was set at $10 \mathrm{~cm}$ and $10 \mathrm{~g}$ for length and weight sizes.

The length-weight relationship (LWR) of the fish was expressed with the following equation (Froese 2006):

$$
W=a L^{b}
$$

where: $\mathrm{W}$ is the total weight $(\mathrm{g}), \mathrm{L}$ is the total length (mm), $a$ is the constant showing the initial growth index, and $b$ is the slope showing growth coefficient. The $b$ exponent with a value between 2.5 and 3.5 is used to describe typical growth dimensions of relative wellbeing of fish population (Bagenal 1978). Analysis of covariance was applied to check any differences between males and females in term of growth pattern. The statistical significance of isometric exponent $(b)$ was analyzed with the following function (Pauly 1984):

$$
t=\left(\frac{S D(x)}{S D(y)}\right)\left(\frac{|b-3|}{\sqrt{1-R^{2}}}\right)(\sqrt{n-2)}
$$


where $t$ is the $t$ student statistics test value, SD (x) is the standard deviation of $\log \mathrm{L}, \mathrm{SD}(\mathrm{y})$ is the standard deviation of $\log \mathrm{W}, b$ is the slope of the curve, $\mathrm{R}^{2}$ is coefficient determination, and $n$ is the number of samples. The $t$-value was compared with the $t$-table value $(0.05)$ for degrees of freedom at a $95 \%$ significance level. If the $t$-value was less than the $t$-table value, this indicated that the fish grew isometrically $(b=3)$. If the $t$-value was greater than the $t$-table value, this indicated that the fish grew allometrically $(b \neq 3)$. The $b$ value has an important biological meaning (Froese 2006); isometric growth indicates that all body dimensions grow at the same rate. When weight increases more than length, it shows positive allometric growth $(b>3)$, but when length increases more than weight, it indicates negative allometric growth $(b<3)$. The maximum and minimum length thresholds for individuals were also estimated to determine whether there were any changes in growth patterns during their life histories. The determination $\left(\mathrm{R}^{2}\right)$ and regression $(\mathrm{r})$ coefficients of morphological variables between males and females were also computed.

The ratio of body depth to the total length (BD/TL) was determined with the non-dimension number based on the empirical method. The condition factor $(\mathrm{K})$ of fish was estimated using the following formula (Weatherley and Gill 1987):

$$
K=100\left(W / L^{3}\right)
$$

where $\mathrm{K}$ is Fulton's condition factor, $\mathrm{L}$ is total length $(\mathrm{cm})$, and $\mathrm{W}$ is weight $(\mathrm{g})$. A factor of 100 was used to bring $\mathrm{K}$ close to the value of one. The $\mathrm{K}$ value is used in assessing the health condition of fish of different sex and in different seasons. The relative condition factor $(\mathrm{Kn})$ was further estimated with the Le Cren (1951) formula:

$$
K n=W \times \hat{\mathrm{W}}^{-1}
$$

where $\mathrm{Kn}$ is the relative condition factor of the fish, $\mathrm{W}$ is the observed weight, and $\mathrm{W}$ is the calculated weight derived from length-weight relationship. The metric indicates that the higher the Kn value, the better the condition of the fish.
The length at first capture $\left(\mathrm{L}_{\mathrm{c} 50}\right)$ is the total length at which $50 \%$ of individuals are caught with purse seines. It also indicates that $50 \%$ of the recruits are under full exploitation. The probability of capture is estimated by plotting the cumulative frequency of the catch (\%) with the total length ( $\mathrm{mm})$, and it is analyzed using a standard selectivity logistic curve (Saputra 2009). This is taken at $50 \%$ of the resultant cumulative curve.

The selection factor (SF) is the index related to the escapement factor expressing the relation between $\mathrm{L}_{\mathrm{c} 50}$ and the mesh size involved. This is also known as the coefficient of selectivity. The selection factor for shortfin scad was simply estimated using the following formula (Pauly 1984):

$$
S F=\frac{L_{c 50}}{\text { Mesh size }}
$$

The mesh size used as the main input for calculating the $\mathrm{SF}$ value was $50.8 \mathrm{~mm}$ for both males and females. The SF value was derived from the corresponding $\mathrm{L}_{\mathrm{c} 50}$ values $(180-185 \mathrm{~mm})$ and the mesh size used.

The $t$-test was applied to compare body sizes, size ratios, and condition factors between males and females. All tests were analyzed at a 0.05 level of significance using SPSS-18 software.

\section{Results}

All estimated length-weight relationship parameters, body size ratios, and condition factors including the length at first capture, and the selection factors of shortfin scad are presented in Tables 1 and 2. Significant differences were noted in total length and body weight between males and females $(\mathrm{P}<0.01)$. The male body size range was 155-223 mm TL (186.56 $\pm 12.60 \mathrm{~mm})$ and $37-110 \mathrm{~g} \mathrm{~W}(60.45 \pm 13.94 \mathrm{~g})$; while those of females were 152-225 mm TL $(191.19 \pm 13.64 \mathrm{~mm})$ and $42-108 \mathrm{~g} \mathrm{~W}(67.10 \pm$ $15.07 \mathrm{~g})$. The sex ratio of male to female was $1.3: 1$.

The body shapes of both males and females showed isometric growth patterns (Fig. 2), indicating 
Table 1

Estimated length-weight parameters of shortfin scad (D. macrosoma) landed at Banjarmasin fishing port

\begin{tabular}{lllllllllll}
\hline \hline & & \multicolumn{3}{c}{ Total length $(\mathrm{mm})$} & \multicolumn{2}{c}{ Weight $(\mathrm{g})$} & & & & \\
Sex & $\mathrm{n}$ & Min & Max & Min & Max & $\mathrm{a}$ & $\mathrm{b}$ & $\mathrm{R}^{2}$ & $\mathrm{r}$ \\
\hline \hline Male & 178 & 155 & 223 & 37 & 110 & $0.80 \times 10^{-5}$ & 3.02 & 0.881 & 0.939 \\
Female & 135 & 152 & 225 & 42 & 108 & $0.10 \times 10^{-4}$ & 2.96 & 0.893 & 0.945 \\
\hline \hline
\end{tabular}

$\mathrm{n}=$ Number of fish samples, $\mathrm{a}=$ constant, $\mathrm{b}=$ exponent, $\mathrm{R}^{2}=$ determination coefficient, $\mathrm{r}=$ regression coefficient

Table 2

Ratio of main body sizes of the shortfin scad (D. macrosoma) landed at Banjarmasin fishing port

\begin{tabular}{llllllllllll}
\hline \hline Sex & $\mathrm{n}$ & $\mathrm{W} / \mathrm{TL}$ & $\mathrm{a}$ & $\mathrm{b}$ & $\mathrm{R}^{2}$ & $\mathrm{r}$ & $\mathrm{BD} / \mathrm{TL}$ & $\mathrm{a}$ & $\mathrm{b}$ & $\mathrm{R}^{2}$ & $\mathrm{r}$ \\
\hline \hline Male & 178 & $0.32 \pm 0.05$ & $0.80 \times 10^{-5}$ & 2.0251 & 0.7686 & 0.8767 & $0.19 \pm 0.02$ & $0.70 \times 10^{-2}$ & 0.6293 & 0.2021 & 0.4496 \\
Female & 135 & $0.35 \pm 0.05$ & $0.40 \times 10^{-4}$ & 1.7296 & 0.6226 & 0.7891 & $0.20 \pm 0.02$ & $0.80 \times 10^{-2}$ & 0.6048 & 0.1938 & 0.4402 \\
\hline \hline
\end{tabular}

$\mathrm{n}=$ Number of fish samples, $\mathrm{a}=$ constant, $\mathrm{b}=$ exponent, $\mathrm{R}^{2}=$ determination coefficient, $\mathrm{r}=$ regression coefficient, $\mathrm{TL}=$ total length, $\mathrm{W}=$ body weight, $\mathrm{BD}=$ body depth

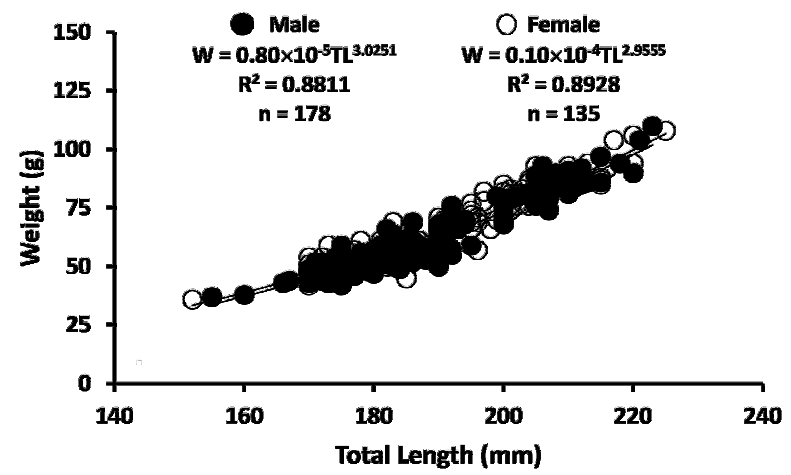

Figure 2. Relationship between body weight and total length of the shortfin scad (D. macrosoma) landed at Banjarmasin fishing port. Both males and females showed isometric growth patterns.

that the length and body weight of the fish increased in equal proportions. The length-weight relationships for males and females were expressed as: $\mathrm{W}=$ $0.80 \times 10^{-5} \mathrm{TL}^{3.0251}$ and $\mathrm{W}=0.10 \times 10^{-4} \mathrm{TL}^{2.9555}$, respectively. The estimated $b$ values in the LWR equations were 3.02 for males and 2.96 for females. The $t$-test values for males and females were less than the $t$-table values confirming that the fish grew isometrically. The $\mathrm{R}^{2}$ values range was $0.881-0.893$ indicating that more than $88 \%$ of weight variability was explained by length. The male and female regression correlations were 0.939 and 0.945 , which were higher than 0.5 and indicated that the length-weight relationship was strongly correlated. Regardless of sex, we observed that individuals smaller than $180 \mathrm{~mm}$ TL grew negatively allometrically with an exponent lower than the cubic value ( $\left.b=2.65, \mathrm{R}^{2}=0.925\right)$, while individuals larger than $209 \mathrm{~mm}$ TL grew positively allometrically with an exponent comparatively higher than the cubic value $\left(b=3.37, \mathrm{R}^{2}=0.932\right)$.

As shown in Table 2, the mean ratio of body weight to total length (W/TL) of females was significantly higher that of males $(\mathrm{P}<0.001)$. The mean $\mathrm{W} / \mathrm{TL}$ ratios obtained for females and males were $0.35 \pm 0.05(0.237-0.482)$ and $0.32 \pm 0.05$ (0.238-0.493), respectively. Females also had a greater mean body depth $(38.44 \pm 5.52 \mathrm{~mm})$ than males $(35.99 \pm 5.17 \mathrm{~mm})$. The increased body depth was directly proportional to total length. The relationship between body depth and total length were provided by the following equations: $\mathrm{BD}=0.84 \times$ $10^{-2} \mathrm{TL}^{1.6048}\left(\mathrm{R}^{2}=0.6287\right)$ for females, and $\mathrm{BD}=$ $0.71 \times 10^{-2} \mathrm{TL}^{1.6293}\left(\mathrm{R}^{2}=0.6293\right)$ for males (Fig. 3). The regression correlation $(\mathrm{r}=0.793)$ obtained showing this relationship was also positively correlated. The mean ratio of body depth to total length (BD/TL) of females was considerably higher than that of males $(\mathrm{P}<0.0001)$. The mean $\mathrm{BD} / \mathrm{TL}$ ratios estimated for females and males were $0.20 \pm 0.02$ (0.162-0.283) and $0.19 \pm 0.02(0.158-0.295)$, respectively. 


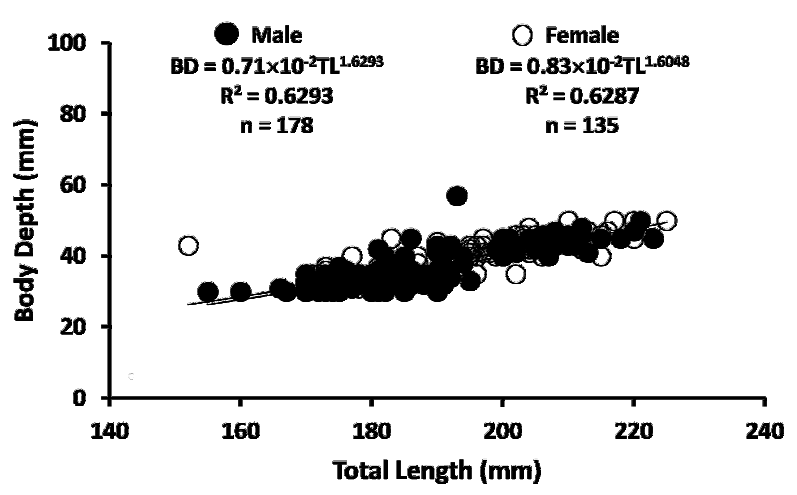

Figure 3. Relationship between body depth and total length of shortfin scad (D. macrosoma). Body depth increased proportionally to total length.

The Fulton's condition factor $(\mathrm{K})$ value of females was significantly higher than that of males $(\mathrm{P}<0.05)$. The $\mathrm{K}$ values obtained ranged from 0.729 to 1.009 $(0.92 \pm 0.07)$ for males and from 0.711 to 1.139 $(0.95 \pm 0.07)$ for females. The available data indicated that the relative condition factor $(\mathrm{Kn})$ value of females was also significantly higher than that of males $(\mathrm{P}<0.0001)$. The Kn values obtained for males ranged from 0.799 to $1.209(1.01 \pm 0.07)$, while for females it ranged from 0.897 to $1.433(1.20$ \pm 0.09 ), which reflected the good condition of the fish samples. The estimated $\mathrm{K}$ and $\mathrm{Kn}$ values are presented in Table 3.

The fish samples in the present study were mostly distributed in the middle size class (Fig. 4A). The highest percentage of the catch was $40.45 \%$ for males and $32.59 \%$ for females, which falls between 180 and $189 \mathrm{~mm}$ TL, followed by 200 and $209 \mathrm{~mm}$ TL (25.19\%) for females and between 170 and $179 \mathrm{~mm}$
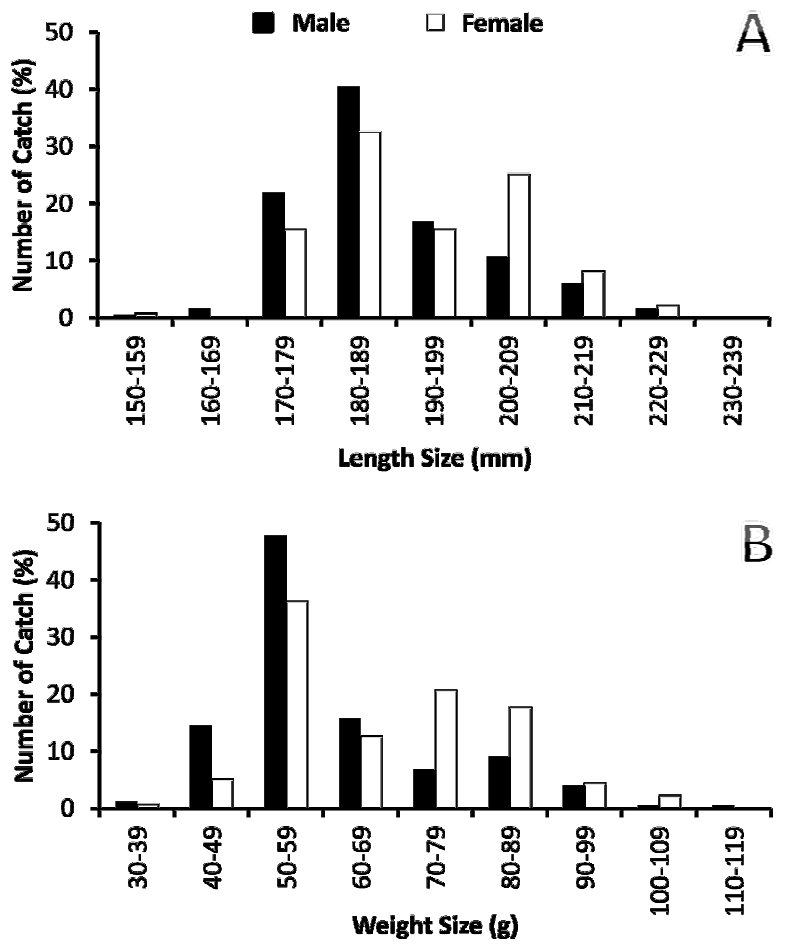

Figure 4. Percentages of length (a) and weight (b) size distributions between male and female shortfin scad (D. macrosoma) collected at Banjarmasin fishing port.

TL (21.91\%) for males. A low number of catch was observed for both smaller individuals $<170 \mathrm{~mm}$ TL $(<$ $2 \%)$ and larger individuals $>219 \mathrm{~mm}$ TL $(<3 \%)$. The heaviest catch of males (47.75\%) and females (36.30\%) weighed between 50 and 59 g. The body weight of females was greater than that of males weighing over $70 \mathrm{~g}$ (Fig. 4B). The t-test analysis showed that there were significant differences in individual class intervals of the length-weight size ranges between males and females $(\mathrm{P}<0.05)$, particularly in

Table 3

Descriptive statistics of the parameters observed in shortfin scad (D. macrosoma) collected from Banjarmasin fishing port

\begin{tabular}{|c|c|c|c|c|c|}
\hline \multirow{2}{*}{$\begin{array}{l}\text { Parameters } \\
\text { Observed }\end{array}$} & \multicolumn{2}{|c|}{ Mean \pm SD of Body sizes } & \multicolumn{3}{|c|}{ t-test for Equality of Means } \\
\hline & Male $(\mathrm{n}=178)$ & Female $(n=135)$ & $\mathrm{t}$ & $\mathrm{df}$ & Sig. (2-tailed) \\
\hline TL (mm) & $186.56 \pm 12.60$ & $191.19 \pm 13.64$ & -3.107 & 311 & 0.002 \\
\hline $\mathrm{W}(\mathrm{g})$ & $60.45 \pm 13.94$ & $67.10 \pm 15.07$ & -4.228 & 311 & 0.000 \\
\hline $\mathrm{BDD}(\mathrm{mm})$ & $35.99 \pm 5.17$ & $38.44 \pm 5.52$ & -4.032 & 311 & 0.000 \\
\hline $\mathrm{W} / \mathrm{TL}$ & $0.32 \pm 0.05$ & $0.35 \pm 0.05$ & -4.392 & 311 & 0.000 \\
\hline $\mathrm{BDD} / \mathrm{TL}$ & $0.19 \pm 0.02$ & $0.20 \pm 0.02$ & -3.715 & 311 & 0.000 \\
\hline $\mathrm{K}$ & $0.92 \pm 0.07$ & $0.95 \pm 0.07$ & -3.480 & 311 & 0.001 \\
\hline $\mathrm{Kn}$ & $1.01 \pm 0.07$ & $1.20 \pm 0.09$ & -20.944 & 311 & 0.000 \\
\hline
\end{tabular}

$\mathrm{TL}=$ total length, $\mathrm{W}=$ body weight, $\mathrm{BDD}=$ body depth, $\mathrm{K}=$ Fultons' condition factor, $\mathrm{Kn}=$ relative condition factor 
Table 4

Significance test for the shortfin scad (D. macrosoma) based on the range of length-weight size distribution

\begin{tabular}{|c|c|c|c|c|c|}
\hline \multirow[b]{2}{*}{ The length size } & \multicolumn{2}{|c|}{ Number of Catch } & \multicolumn{3}{|c|}{ t-test for Equality of Means } \\
\hline & Male & Female & $\mathrm{t}$ & $\mathrm{df}$ & Sig. (2-tailed) \\
\hline $150-159$ & 1 & 1 & - & 0 & \\
\hline $160-169$ & 3 & 0 & 37.591 & 2 & 0.001 \\
\hline $170-179$ & 39 & 21 & 0.518 & 58 & 0.606 \\
\hline $180-189$ & 72 & 44 & 0.636 & 114 & 0.526 \\
\hline 190-199 & 30 & 21 & -5.346 & 49 & 0.000 \\
\hline 200-209 & 19 & 34 & 2.092 & 51 & 0.041 \\
\hline $210-219$ & 11 & 11 & -0.735 & 20 & 0.471 \\
\hline $220-229$ & 3 & 3 & 125.484 & 2 & 0.000 \\
\hline \multirow[t]{2}{*}{ 230-239 } & 0 & 0 & - & 0 & - \\
\hline & \multicolumn{2}{|c|}{ Number of Catch } & \multicolumn{3}{|c|}{ t-test for Equality of Means } \\
\hline The weight size & Male & Female & $\mathrm{t}$ & $\mathrm{df}$ & Sig. (2-tailed) \\
\hline $30-39$ & 2 & 1 & 1.732 & 1 & 0.333 \\
\hline $40-49$ & 26 & 7 & 0.149 & 31 & 0.882 \\
\hline $50-59$ & 85 & 49 & -0.135 & 132 & 0.893 \\
\hline $60-69$ & 28 & 17 & 0.873 & 43 & 0.388 \\
\hline $70-79$ & 12 & 28 & -0.283 & 38 & 0.779 \\
\hline $80-89$ & 16 & 24 & 0.269 & 38 & 0.789 \\
\hline $90-99$ & 7 & 6 & -0.362 & 11 & 0.725 \\
\hline 100-109 & 1 & 3 & -0.866 & 2 & 0.478 \\
\hline $110-119$ & 1 & 0 & - & 0 & - \\
\hline
\end{tabular}

the length size ranges of 160-169 mm, 190-199 mm, The estimated selection factors (SF) for males and fe200-209 mm, and 220-229 mm, but no significant males were 3.54 and 3.64, respectively.

differences in the weight size range between males and females were observed (Table 4).

The length at first capture $\left(\mathrm{L}_{\mathrm{c} 50}\right)$ was estimated at $180 \mathrm{~mm}$ for males and $185 \mathrm{~mm}$ for females, which indicated the sizes at which $50 \%$ of the catches were retained by purse seines. Based on $\mathrm{L}_{\mathrm{c} 50}$, we also roughly estimated the proportion of smaller and larger individuals of scad males retained by the fishing gear at $24.16 \%(<180 \mathrm{~mm})$ and $75.84 \%$ (> $180 \mathrm{~mm}$ ) respectively, while those of scad females were estimated at $32.59 \%(<185 \mathrm{~mm})$ and $67.41 \%(>185$ $\mathrm{mm})$. This indicated that the majority of the

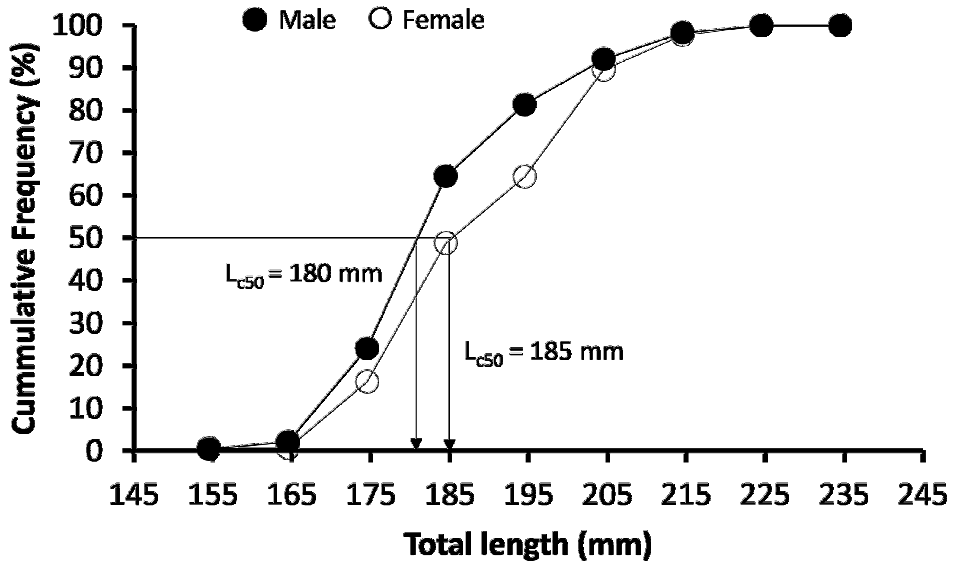

Figure 5. Selectivity logistic curve clearly shows that the estimated $\mathrm{L}_{\mathrm{c} 50}$ values for male and female shortfin scad (D. macrosoma) were 180 and $185 \mathrm{~mm}$, respectively, caught with $50.8 \mathrm{~mm}$ mesh size purse seines. 


\section{Discussion}

The most important result of the present study was that D. macrosoma grew isometrically $(b=$ 2.96-3.02), which indicated that length increased proportionally to body weight. We estimated the maximum and minimum length thresholds for individuals at 179 and $210 \mathrm{~mm}$ to determine the range of size distribution in which fish showed an isometric growth pattern or shifts in their growth patterns. Such a growth pattern was in agreement with $D$. macrosoma from the Eastern Java Sea of Central Java (Prihartini et al. 2007), D. russelli from the Mumbai waters and Mangaluru of India (Jaiswar et al. 2001, Ashwini et al. 2016), Decapterus tabl Berry from the Camotes Sea of the Philippines (Narido et al. 2016), and Decapterus maruadsi (Temnick \& Schlegel) from the Gulf of Suez of Egypt (Mehanna et al. 2015). However, it was contrary to D. macrosoma from the Ambon Island of the Maluku and Makassar waters of South Sulawesi (Pattikawa et al. 2017, Asni et al. 2019), D. russelli from the Mumbai waters of India (Panda et al. 2011), the Latulahalat waters of Maluku (Ongkers et al. 2016), and D. tabl from Suruga Bay of Japan (Iwasaki and Aoki 2001), which all displayed positive allometric growth patterns. Meanwhile, D. macarellus from the North Maluku Sea (Iksan and Irham 2009), D. russelli from the northern Arabian Sea of Pakistan (Kalhoro et al. 2017), and D. macrosoma from PPI Sanggeng-Manokwari of West Papua (Randongkir et al 2018) exhibited negative growth patterns or slower growth when compared to our findings (Table 5). Variation in slope could be attributed to sample size variation, life stages, growth difference, seasonal fluctuations, changes in physiological condition during spawning periods, gonad development, sex, or environmental factors such as food and space (Mehanna et al. 2015, Ashwini et al. 2016, Kalhoro et al. 2017).

The spawning period of shortfin scad is around April and May, and fishing activities could be done when spawning is completed. This also implies that fishes caught in the spawning period are likely to be heavier than those caught afterward. Since the catch data were collected in July, the results of this study were still applicable. In Banda Neira of Maluku, $D$. macrosoma was reported spawning between February and March (Senen et al. 2011). While in Ambon Bay (eastern Indonesia), it was occurred twice a year between July and August and between November and December (Syahailatua and Sumadhiharga 1996). When fishing intensity increases, it can disturb spawning activity and also adversely impact spawning habitats (van Overzee and Rijnsdorp 2014). Establishing seasonal area closures during spawning periods is not only beneficial for ecological aspects but also for the socio-economic aspects of the fishing community itself (Clarke et al. 2015).

In the present work, the purse seine was considered to be male-biased gear as indicated by the male catch ratio that was 1.3 times higher than that for females. This might be attributable to reproductive and migration cycles during which spawning females migrate out of the fishing grounds. A higher proportion of males to females has also been documented for $D$. macrosoma from PPI Sadeng of Yogyakarta (Liestiana et al. 2015), D. russelli from Mangaluru of India (Ashwini et al. 2016), and D. macrosoma from the Makassar waters of South Sulawesi (Asni et al. 2019). Meanwhile, a female-biased ratio was reported for D. macrosoma from Javanese waters (Prihatini et al. 2007) and for D. macarellus from North Maluku (Iksan and Irham 2009). Variations in fish sex ratios are closely related to food availability, water temperature, dissolved oxygen, migration cycle, and geographical differences (Poojary et al. 2015, Awan et al. 2017, Asni et al. 2019).

In the present study, the mean $\mathrm{K}$ and $\mathrm{Kn}$ values obtained for D. macrosoma females were comparatively higher than those for males (see Table 3), and the values were close or equal to those that indicated the scad were in good condition. Compared to other species, the current $\mathrm{K}$ values were relatively similar to D. macrosoma from Banda Nera Island of Maluku and PPI Sadeng of Yogyakarta (Senen et al. 2011, Liestiana et al. 2015) and D. russelli from Maharashtra and Mangaluru of India (Poojary et al. 2015, Ashwini et al. 2016), but these K values were 
Table 5

Comparative length-weight relationship, condition factor, and growth patterns of shortfin scad (D. macrosoma) from different geographical areas

\begin{tabular}{|c|c|c|c|c|c|c|c|c|c|c|}
\hline \multirow[b]{2}{*}{ Area of Studies } & \multirow[b]{2}{*}{ Province } & \multirow[b]{2}{*}{ Species } & \multirow[b]{2}{*}{ Sex } & \multirow[b]{2}{*}{$\mathrm{n}$} & \multicolumn{2}{|c|}{ Body size (mm) } & \multirow{2}{*}{$\begin{array}{l}\text {-Growth } \\
\text { pattern }\end{array}$} & \multirow[b]{2}{*}{$\mathrm{b}$} & \multirow[b]{2}{*}{$\mathrm{Kn}$} & \multirow[b]{2}{*}{ References } \\
\hline & & & & & Min & Max & & & & \\
\hline Banjarmasin Fishing Port & South Kalimantan & D. macrosoma & M & 178 & 155 & 223 & I & 3.03 & 1.01 & Present study \\
\hline Banjarmasin Fishing Port & South Kalimantan & D. macrosoma & $\mathrm{F}$ & 135 & 152 & 225 & I & 2.96 & 1.20 & Present study \\
\hline Western Java Sea & Central Java & D. macrosoma & $\mathrm{P}$ & 610 & 96 & 216 & I & 2.98 & $2.08-2.97$ & Prihartini 2006 \\
\hline Makassar waters & South Sulawesi & D. macrosoma & M & 201 & 128 & 340 & A+ & 3.37 & - & Asni et al. 2019 \\
\hline Makassar waters & South Sulawesi & D. macrosoma & $\mathrm{F}$ & 169 & 120 & 330 & A+ & 3.73 & - & Asni et al. 2019 \\
\hline PPI Sadeng, Gunung Kidul & Yogyakarta & D. macrosoma & $\mathrm{P}$ & 1,324 & 145 & 380 & A- & 2.88 & 1.05 & Liestiana et al. 2015 \\
\hline Bone Bay & South Sulawesi & D. macrosoma & $\mathrm{P}$ & 849 & 121 & 295 & - & - & - & Suwarni et al. 2015 \\
\hline PPI Sanggeng, Manokwari & West Papua & D. macrosoma & M & 222 & 109 & 303 & A- & 1.84 & $0.67-1.86$ & Randongkir et al. 2018 \\
\hline PPI Sanggeng, Manokwari & West Papua & D. macrosoma & $\mathrm{P}$ & 278 & 125 & 299 & A- & 2.03 & $0.72-1.80$ & Randongkir et al. 2018 \\
\hline Banda Nera Island & Maluku & D. macrosoma & $\mathrm{P}$ & 1,134 & 75 & 315 & $\mathrm{~A}+$ & 3.19 & 1.11 & Senen et al. 2011 \\
\hline Ambon Island & Maluku & D. macrosoma & $\mathrm{P}$ & 1,018 & 133 & 315 & $\mathrm{~A}+$ & 3.59 & - & Pattikawa et al. 2017 \\
\hline North Maluku & Maluku & D. macarellus & M & 645 & 211 & 311 & A- & 2.28 & - & Iksan and Irham 2009 \\
\hline North Maluku & Maluku & D. macarellus & $\mathrm{F}$ & 1,355 & 215 & 315 & A- & 2.98 & - & Iksan and Irham 2009 \\
\hline Eastern Java Sea & Central Java & D. russelli & $\mathrm{P}$ & 756 & 86 & 214 & I & 3.03 & $1.66-2.23$ & Prihartini 2006 \\
\hline Northwest coast & India & D. russelli & $\mathrm{P}$ & 1,831 & 80 & 218 & I & 3.00 & - & Jaiswar et al. 2013 \\
\hline Latulahalat, Ambon Island & Maluku & D. russelli & M & 220 & 75 & 235 & $\mathrm{~A}+$ & 3.63 & - & Ongkers et al. 2016 \\
\hline Latulahalat, Ambon Island & Maluku & D. russelli & $\mathrm{F}$ & 223 & 94 & 286 & A+ & 3.89 & - & Ongkers et al. 2016 \\
\hline Mangaluru & India & D. russelli & M & 667 & 110 & 230 & I & 3.02 & 1.02 & Ashwini et al. 2016 \\
\hline Mangaluru & India & D. russelli & $\mathrm{F}$ & 339 & 130 & 220 & I & 3.09 & 1.05 & Ashwini et al. 2016 \\
\hline Northern Arabian Sea & Pakistan & D. russelli & $\mathrm{P}$ & 997 & 10 & 310 & A- & 2.66 & - & Kalhoro et al. 2017 \\
\hline Maharashtra & India & D. russelli & $\mathrm{P}$ & 812 & 110 & 229 & - & - & 0.93-1.08 & Poojary et al. 2015 \\
\hline Mumbai waters & India & D. russelli & $\mathrm{P}$ & 235 & 142 & 230 & $\mathrm{~A}+$ & 3.17 & - & Panda et al. 2011 \\
\hline Malabar & India & D. russelli & M & 193 & 65 & 242 & A- & 2.32 & - & Manojkumar 2007 \\
\hline Malabar & India & D. russelli & $\mathrm{F}$ & 179 & 65 & 242 & I & 2.98 & - & Manojkumar, 2007 \\
\hline Gulf of Suez & Egypt & D. maruadsi & $\mathrm{P}$ & 1,864 & 73 & 251 & I & 2.90 & - & Mahenna et al. 2015 \\
\hline Camotes Sea & Philippines & D. tabl & $\mathrm{P}$ & 317 & 125 & 314 & I & 2.99 & - & Narido et al. 2016 \\
\hline Suruga Bay & Japan & D. $t a b l$ & $\mathrm{P}$ & $\ldots$ & 180 & 430 & $\mathrm{~A}+$ & 3.18 & - & Iwasaki and Aoki 2001 \\
\hline
\end{tabular}

A+ - positive allometric; A- - negative allometric; I - isometric; W - weight; TL - total length; Kn - relative condition factor; $\mathrm{M}$ - male; F - female; $\mathrm{P}$ - pooled

lower than those for D. russelli from the Eastern Java Sea of Central Java or for D. macrosoma landed in PPI Sanggeng of West Papua (Randongkir et al. 2018). Variations in K values can be attributed to biological interactions involving intraspecific competition for food and space among species including sex, stage of maturity, and food availability (Poojary et al. 2015, Ashwini et al. 2016).
The estimated $\mathrm{L}_{\mathrm{c} 50}$ values for D. macrosoma (180-185 mm) landed at Banjarmasin fishing port were comparatively lower than for D. macrosoma (255 mm) landed at PPI Sadeng of Yogyakarta (Liestiana et al. 2015) or for D. macrosoma (201 mm) landed at PPN Pekalongan (Prihatini et al. 2007), but they were relatively higher than the $\mathrm{L}_{\mathrm{c} 50}$ values for $D$. tabl $(175 \mathrm{~mm})$ from the Camotes Sea of the Central Philippines (Narido et al. 2016). This variation can 
be affected by many factors such as time and duration of sampling, number and size of fish sampled, as well as the type and mesh size of the fishing gear used. Because of the effect of fishing pressure or environmental changes (e.g., water temperature and food availability), scad behavior can shift from a pelagic to a demersal mode of life as they increase in size, hence larger fish may not be caught by these gears. Based on an example of purse seine fishery in the Pagasitikos Gulf of Greece, catches were also restricted by the maximum height of the purse seine $( \pm$ $30 \mathrm{~m}$ ), which implied that any species below this depth were out of reach (Tsitsika and Maravelis 2006).

Based on the $50.8 \mathrm{~mm}$ (2-inch) mesh size of the purse seine, the selection factor (3.54-3.64) for $D$. macrosoma in the present study was relatively lower than that landed in PPI Sadeng of Yogyakarta (5.02) (Liestiana et al. 2015). However, the current SF values obtained were comparatively higher than those for Sardinella aurita Val. (1.63) and Sardinella maderensis (Lowe) (1.83), which corresponded to an $83 \mathrm{~mm}$ mesh size (Ofori-danson et al. 2018). Seemingly, the value of the selection factor increased with mesh size and the corresponding $\mathrm{L}_{\mathrm{c} 50}$ value for this species. These SF values were large enough to show that the purse seine can be considered a selective fishing gear for D. macrosoma since two-thirds of total catch comprised larger individuals between 181-225 mm TL. The selection factor of the purse seine was not only determined by the mesh size, but it was also affected by gear construction, fish behavior, and netting materials (Widjopriono and Mahiswara 2008).

Thomson and Ben-Yami (1984) classified purse seines as less selective fishing gear because the fish species caught with them exhibited a wider range of sizes or ages than did fishes caught with gill nets. In point of fact, Javanese fishers that still operated purse seines with a smaller mesh size $(38 \mathrm{~mm})$ to catch the mackerel scad led to fish population declines (Prihartini et al. 2007). It is acknowledged that purse seines have higher productivity in comparison with other fishing gears such as beach seines, drift gillnets, and mini trawls (Yonvitner et al. 2020).
Besides using larger mesh sizes $(63-76 \mathrm{~mm})$, the selectivity of purse seine can be improved by installing rigid metal sorting grids in the pocket sections (Beltestad and Misund 1995) or panels of diamond-shaped meshed can be inserted in the posterior parts (Goncalves et al. 2004) to reduce and minimize fisheries by-catch. Moreover, the sinking performance of purse seines with larger mesh-sized panels and heavier material was also simulated numerically (Hosseini et al. 2011). Although the existing scad fishery is sustainable, precautionary control measures should be taken into consideration. Therefore, further improvement of real-time monitoring of catch per unit effort (CPUE) in the investigated area should be done to ensure that fish continue to be landed in good, marketable condition and that they are not being fully exploited. Fishing intensity should be rationalized to effectively prevent the overexploitation of the scad population.

Acknowledgments. This research was undertaken with our own means of funding. We extend our thanks to Mr. Erwan Shafari from Banjarmasin fishing port for facilitating this research and to Mrs. Siti Ubaidah for assisting during fieldwork and measurements. Our gratitude also goes to the reviewers for significantly improving the contents of the manuscript to a publishable level.

ORCID ID

Ahmadi: (iD https://orcid.org/0000-0001-9691-9107

\section{References}

Ashwini L., Benakappa S., Anjanayappa H.N., Akshay 2016 Length-weight relationship and condition factor of Decapterus russelli from Mangaluru Region - Int. J. Engineer. Sci. Comput. 6: 7084-7087.

Asni A., Hamsiah, Rustam, Ilmiah 2019 - Biological aspects of Shortfin scad (Decapterus macrosoma) in Makassar waters, South Sulawesi, Indonesia - IOP Conf. Series: Earth and Environmental Science 253: 012008.

Atmaja S.B., Sadhotomo B. 2005 - Study on the reproduction of „layang deles“ shortfin scad (Decapterus macrosoma) in the Java Sea - Indonesian Fish. Res. J. 11: 9-18.

Awan K.P., Qamar N., Farooq N., Panhwar S.K. 2017 - Sex ratio, length weight relationships and condition of eight 
fish species collected from Narreri Lagoon, Badin, Sindh, Pakistan - J. Aqua. Mar. Biol. 5: 00130.

Bagenal T.B. 1978 - Methods for assessment of fish production in freshwaters. 3rd ed. - Blackwell Scientific Publication, London, Oxford.

Bagenal T.B., Tesch F.W. 1978 - Age and growth - In: Methods for assessment of fish production in freshwater (Ed.) T.B. Bagenal, Blackwell Scientific Publications., London, Oxford: 101-136.

Beltestad A.K., Misund OA. 1995 - Size selection in purse seines. In: Solving bycatch: considerations for today and tomorrow Alaska Sea Grant College Program Report No 96-03.

Clarke J., Bailey D.M., Wright P.J. 2015 - Evaluating the effectiveness of a seasonal spawning area closure - ICES J. Mar. Sci. 72: 2627-2637.

Froese R. 2006 - Cube law, condition factor and weight-length relationships: history, meta-analysis and recommendations - J. Appl. Ichthyol. 22: 241-253.

Ghorbani, A., Salamatdoustnobar R., Ghaem M.S.S., Motallebi V. 2012 - The effect of different levels of prebiotic on the length of fingerling rainbow trout - African J. Biotech. 11: 8928-8931.

Goncalves J.M.S., Bentes L., Monteiro P., Coelho R., Corado M., Erzini K. 2004 - Reducing discards in a demersal purse seine fishery - Aquat. Living Resour. 21: 135-144.

Hanif M.S., Iqbal K.J., Javid A., Khan N., Irfan, Majeed H., Altaf M. 2019 - Socio economic status of fishermen community, south Punjab, Pakistan - Punjab Univ. J. Zool. 34: 115-118.

Hsieh C.H., Yamauchi A., Nakazawa T., Wang W.F. 2010 Fishing effects on age and spatial structures undermine population stability of fishes - Aquat. Sci. 72: 165-178.

Hosseini S.A., Lee C.W., Kim H.S., Lee J., Lee G.H. 2011 The sinking performance of the tuna purse seine gear with large-meshed panels using numerical method Fish. Sci. 77: 503-520.

Iksan K.H., Irham. 2009 - Pertumbuhan dan reproduksi ikan layang biru (Decapterus macarellus) di perairan Maluku Utara - J. Iktiol. Indonesia. 9: 163-174 (in Indonesian).

Iwasaki Y., Aoki M. 2001 - Length-weight relationship, maturity and spawning season of the northern mackerel scad Decapterus tabl Berry in Suruga Bay, Central Japan Bull. Inst. Ocean Res. Dev. Tokai University. 22: 93-100.

Jaiswar A.K., George J.P., Gulati D.K., Swamy R.P. 1993 - A study on length-weight relationship, food and feeding habits of Indian scad, Depaterus russelli (Ruppell, 1830) along the Northwest coast of India - J. Indian Fish. Ass. 23: 1-6.

Jaiswar A.K., Chakraborty S.K., Swamy R.P. 2001 - Studies on the age, growth and mortality rates of Indian scad Decapterus russelli (Ruppell) from Mumbai waters Fish. Res. 53: 303-308.

Jorgensen C., Ernande B., Fiksen O. 2009 - Size-selective fishing gear and life history evolution in the Northeast Arctic cod - Evol. Appl. 2: 356-370.
Kalhoro M.T., Yongtong M., Kalhoro M.A., Mahmood M.A., Hussain S.S.B, Mahmood M.A., Muhammad M., Ramesh P.T. 2017 - Stock assessment of Indian scad, Decapterus russelli in Pakistani marine waters and its impact on the national economy - Fish. Aqua. J. 8: 200.

Kalita G.J., Sarma P.K., Rout G.S. 2015 - Socioeconomic status of fishermen and different fishing gear used in Beki River, Barpeta, Assam - J. Entomol. Zool. Stud. 3: 193-198.

Kigbu A., Ibrahim H.Y., Madaki, R.D., Ogezi E. 2014 Socio-economic activities of fishing communities and its effects on the status of fishery resources in Lake Feferuwa Nasarawa State, North Central, Nigeria - Livest. Res. Rural Dev. 26(12): 226.

Kimura S., Katahira K., Kuriiwa K. 2013 - The red-fin Decapterus group (Perciformes: Carangidae) with the description of a new species, Decapterus smithvanizi Ichthyol. Res. 60: 363-379.

Le-Cren E.D. 1951 - The length-weight relationship and seasonal cycle in gonad-weight and condition in the Perch (Perca fluviatilis) - J. Anim Ecol. 20: 201-219..

Liang Z., Sun P., Yan W., Huang L., Tang Y. 2014 - Significant effects of fishing gear selectivity on fish life history J. Ocean Univ. China 13: 467-471.

Liestiana H., Ghofur A., Rudiyanti S. 2015 - Biological aspects of the shortfin scad (Decapterus macrosoma) caught at sadeng fishing base, Gunungkidul, Yogyakarta - Diponegoro J. Maquares. 4: 10-18 (in Indonesian).

Manojkumar P.P. 2007 - Stock assessment of Indian scad, Decapterus russelli (Ruppell, 1830) off Malabar - J. Mar. Biol. Ass. India 49: 76-80.

Mansor M.I., Abdullah S. 1995 - Growth and mortality of Indian mackerel (Rastrelliger kanagurta) and slender scad (Decapterus russelli) off the east coast of Peninsular Malaysia - Sci. Mar. 59: 533-547.

McBride R.S., Stengard F.J., Mahmoudi B. 2002 - Maturation and diel reproductive periodicity of Round scad (Carangidae: Decapterus punctatus) - Mar. Biol. 140: 713-722.

Mehanna S.F., Khalil M.T., Ahmed M.H.M., El Kafrawy S.B., El-Sherbeny A.S.H. 2015 - Growth, mortality and relative yield per recruit of Japanese scad Decapterus maruadsi (Temminck \& Schlegel, 1842) in the Gulf of Suez, Red Sea, Egypt - Egyptian J. Aquat. Biol. Fish. 19: 1-6.

Misnan R., Murad S., Jones M., Taylor G., Rahman D., Arip M., Abdullah N., Mohamed J. 2008 - Identification of the major allergens of Indian scad (Decapterus russelli) Asian Pacific J. Allergy Immunol. 26(4): 191-198.

Nababan R., Wibowo B.A., Boesono B. 2014 - The analysis of factors that influencing the price of Round scad (Decapterus spp) that caught using mini purse seine in Tasikagung fishing port of Rembang Central Java - J. Fish. Res. Utiliz. Man. Tech. 3: 113-121 (in Indonesian).

Narido C.I., Palla H.P., Argente F.A.T., Geraldino P.J.L. 2016 - Population dynamics and fishery of Roughear scad Decapterus 
tabl Berry 1968 (Perciformes: Carangidae) in Camotes Sea, Central Philippines - Asian Fish. Sci. 29: 14-27.

Ohshimo S., Yoda M., Itasaka N., Morinaga N., Ichimaru T. 2006 - Age, growth and reproductive characteristics of Round scad Decapterus maruadsi in the waters off west Kyushu, the East China Sea - Fish. Sci. 72: 855-859.

Ohshimo S., Shiraishi T., Tanaka H., Yasuda T., Yoda M., Ishida H., Tomiyasu S. 2014 - Growth and reproductive of the Roughear scad, Decapterus tabl in the East China Sea - JARQ, 28: 245-252.

Ongkers O.T.S., Pattikawa J.A., Rijoly F. 2016 - Aspek biologi ikan Layang (Decapterus russelli) di perairan Latuhalat, Kecamatan Nusaniwe, Pulau Ambon - Omni-Akuatika 12: 79-87 (in Indonesian).

Ofori-danson P.K., Addo S., Animah C.A., Abdulhakim A., Nyarko J.O. 2018 - Length at first capture $\left(\mathrm{L}_{\mathrm{C} 50}\right)$ of Sardinella aurita and Sardinella maderensis landed from purse seines at the Tema fishing harbour, Ghana - Int. J. Fish. Aquat. Res. 3: 8-13.

Ory N.C., Sobral P., Ferreira J.L., Thiel M. 2017 - Amberstripe scad Decapterus muroadsi (Carangidae) fish ingest blue microplastics resembling their copepod prey along the coast of Rapa Nui (Easter Island) in the South Pacific subtropical Gyre - Sci. Total Environ. 586: 430-437.

Panda D., Chakraborty S.K., Jaiswar A.K., Kumar T., Behera P.K. 2011 - Comparative length-weight relationship of two species of carangids Decapterus russelli (Ruppell, 1830) and Megalaspis cordyla (Linnaeus, 1758) from Mumbai waters - Indian J. Fish. 58: 33-37.

Pattikawa J.A., Tetelepta J.M.S, Ongkers O.T.S., Uneputty P.A., Lewerissa H. 2017 - Size distribution, length-weight relationship and age group of Decapterus macrosoma in eastern waters of Ambon Island, Indonesia - AACL Bioflux. 10: 969-976

Pauly D. 1984 - Fish population dynamics in tropical waters: a manual for use with programmable calculations ICLARM Stud. Rev. 8:1-325.

Piliana W.O., Kusumastanto T., Diniah 2015 - Bioeconomic analysis and resource management optimization of mackerel scad in Muna district, south east Sulawesi Mar. Fish. 6: 13-22 (in Indonesian).

Poojary N., Tiwari L.R., Sundaram S. 2015 - Reproductive biology of the Indian scad, Decapterus russelli (Ruppell, 1830) from Maharashtra waters, northwest coast of India - J. Mar. Biol. Ass. India. 57(1): 71-77.

Prihatini A., Anggoro S., Asriyanto. 2007 - Biological performance analysis of Layang (Decapterus spp) from the purse seine fishery at the PPN Pekalongan landing place - J. Pasir Laut. 63: 61-75.

Rahman, Ahmadi, Mahreda E.S. 2019 - Marketing channels of marine fish in Banjarmasin fishing port, Indonesia Int. J. Fish. Aquat. Res. 4: 15-22.

Randongkir Y.E., Simatauw F., Handayani T. 2018 - Growth aspects of scad Decapterus macrosoma of fish point
Sanggeng-Manokwari Regency - J. Sumberdaya Akuatik Indopasifik. 2: 15-24 (in Indonesian).

Rasli H.I., Sarbon N.M. 2018 - Optimization of enzymatic hydrolysis conditions and characterization of Shortfin scad (Decapterus macrosoma) skin gelatin hydrolysate using response surface methodology - Int. Food Res. J. 25: 1541-1549.

Saputra S.W. 2009 - Research-Based Fish Population Dynamics - Universitas Diponegoro, Semarang, p. 203 (in Indonesian).

Senen B., Sulistiono, Muchsin I. 2011 - Some aspects of the biology of Shortfin scad (Decapterus macrosoma) on Banda Neira Island, Maluku - J. Pengembangan Pulau-Pulau Kecil, p. 52-60 (in Indonesian).

Shafari E, Ahmadi, Mahyudin I. 2019 - The effectiveness of the subsidized fuel distribution for fish carrier vessels in Banjarmasin Fishing Port, Indonesia - Int. J. Fish. Aquat. Res. 4: 8-14.

Shiraishi T., Tanaka H., Ohshimo S., Ishida H., Morinaga N. 2010 - Age, growth and reproduction of two species of scad, Decapterus macrosoma and D. macarellus in the waters off southern Kyushu - JARQ 44: 197-206.

Suwarni, Tresnati J., Umar M.T., Nur M., Hikmasari. 2015 Estimation of population dynamics parameters of mackerel fish (Decapterus macrosoma, Bleeker 1841) in the waters of Bone Strait, South Sulawesi - Torani: Jurnal Ilmu Kelautan dan Perikanan). 25(1): 53-60 (in Indonesian).

Syahailatua A., Sumadhiharga K. 1996 - Population dynamics of two types of flying fish - Torani. 6: 31-46 (in Indonesian).

Thomson D.B., Ben-Yami M. 1984 - Fishing gear selectivity and performance. Papers presented at the expert consultation on the regulation of fishing effort (fishing mortality) - FAO Fisheries Report No.289 Supplement 2.

Tsitsika E.V., Maravelis C.D. 2006 - Factors affecting purse seine catches: an observer-based analysis - Medit. Mar. Sci. 7: 27-40.

van Overzee H.M.J., Rijnsdorp A.D. 2014 - Effects of fishing during the spawning period: implications for sustainable management - Rev. Fish Biol. Fish. 25: 65-83.

Weatherley A.H., Gill H.S. 1987 - The biology of fish growth Academic Press, London.

Wijopriono, Mahiswara. 2008 - Biometric parameters of catch of purse seine in the Java Sea related to its selectivity performance - J. Penelitian Perikanan Indonesia 14(3): 285-293 (in Indonesian).

Yonvitner, Yuliana E., Yani D.E., Setijorini L.E., Nurhasanah, Santoso, A., Boer M., Kurnia, R., Akmal S.G. 2020 - Fishing gear productivity related fishing intensity and potency of stock vulnerability in Sunda strait - IOP Conference Series: Earth and Environmental Science. 404: 1-10.

Zamroni A., Suwarso. 2017 - Genetic diversity of mackerel scads Decapterus macarellus (Cuvier, 1833) in the Indian Ocean - Indonesian Fish. Res. J. 23: 89-96. 